\title{
Cumulative Effect of Soil and Water Soluble Fertilizer on Physio-biochemical, Nutrient Status of Leaf and its Effect on Postharvest Soil in Cauliflower Production
}

\author{
Krish Rauniyar, Vasant M. Ganiger, T. B. Alloli, G. Bhuvaneswari, \\ J. B. Gopali, S. M. Prasanna and Anand G. Patil \\ Department Vegetable Science, University of Horticultural Sciences, College of Horticulture, \\ Bagalkot, Karnataka, India \\ *Corresponding author
}

A B S T R A C T

\begin{tabular}{|c|}
\hline $\begin{array}{l}\text { Ke y w o r d s } \\
\text { Cauliflower } \\
\text { Production, Physio- } \\
\text { biochemical, } \\
\text { Nutrient Status of } \\
\text { Leaf }\end{array}$ \\
\hline Article Info \\
\hline $\begin{array}{l}\text { Accepted: } \\
18 \text { December } 2020 \\
\text { Available Online: } \\
10 \text { January } 2021\end{array}$ \\
\hline
\end{tabular}

A study was undertaken to assess the efficacy of amalgamating of soil and foliar application in different concentration of fertilizer on quality of cauliflower, leaf nutrient status and post harvest status of soil. Thirteen treatments were taken with different concentration of soil and foliar application. Three foliar formulations were sprayed at early growth stage (20 DAT), medium growth stage (40 DAT), and broad growth stage (60 DAT) during the course of the investigation. The highest ascorbic acid $(45.40 \mathrm{mg} / 100 \mathrm{~g})$, TSS $\left(4.56{ }^{\circ}\right.$ Brix $)$, dry matter content $(11.24 \%)$ and crude fiber $(2.47 \mathrm{~g} / 100 \mathrm{~g})$ and highest leaf nitrogen $(3.18 \%)$, leaf phosphrous $(0.68 \%)$, leaf potassium $(1.34 \%)$ and leaf sulphur $(3.75 \%)$ were recorded superior in the treatment $\mathrm{T}_{10}$. The post harvest status soil was found to be $\mathrm{pH}$ of 7.44 , EC of $0.18 \mathrm{dS} / \mathrm{m}, \mathrm{N} 95.67 \mathrm{~kg} / \mathrm{ha}, \mathrm{P} 18.84 \mathrm{~kg} / \mathrm{ha}$ and $\mathrm{K} 56.67 \mathrm{~kg} / \mathrm{ha}$ respectively. The study revealed that combination of $66 \%$ RDF and $5.0 \%$ foliar spray was best for the cv. Mahima-80 and other cultivars with respect to nutrient status, leaf nutrient and post harvest status of soil.

\section{Introduction}

One of the most popular vegetable among the cole crops in India, cauliflower (Brassica oleracea var. botrytis) widely grown in tropical and temperate regions of the country. It belongs to Brassicaceae family (Chromosome no. $2 \mathrm{n}=2 \mathrm{x}=18$ ). The crop is the native of South Europe in the Mediterranean region and was introduced in India from England in 1822 by Dr. Jemson (Chatterjee and Swarup, 1972). In India, two separate groups of cauliflower are commonly grown $v i z$. Indian or tropical types (originated in India) and the annual temperate or European type also known as Erfurt or Snowball type. It is grown throughout the world, China ranks $1^{\text {st }}$ followed by India, USA, Spain and Mexico. India has an area of 0.43 million hectares and production of 8.57 million tonnes which keeps them second in the world. In India it is grown mainly in states like West Bengal, Bihar, Madhya Pradesh, Haryana and Odisha. West Bengal takes first in both area 
and production of 74.20 ('000 ha) and 1899.58 ('000 MT), respectively. Jammu and Kashmir stands first in productivity. Out of 10.29 million hectares of land under vegetables, cauliflower occupies $2.27 \%$ area. Cauliflower is exported to different countries mainly to neighboring country Nepal, Russia, Saudi Arabia, Maldives and Singapore (Pavan Kumar et al., 2018). The edible part, i.e. curd, is typically white in color, a 'prefloral fleshy apical meristem'. The leaves may enclose the curd before its exposure. The stalk and surrounding dense, green leaves are repudiated which are well off of minerals iron and $\beta$-carotene and can be used as value added products (Kowsalya and Sangeetha, 1999). It is predominant due to its attractive appearance, good taste, easily digestible, rich source of nutrients and high yielding capacity. Compact curds are used as raw cooked vegetables, soups, curries and pickles. For its nutritional value, digestibility and rich in minerals, protein and vitamins, the tender curd of cauliflower is very common. Pachranga and Satranga oil pickles, which include vegetables and fruits in India, are mainly dried or processed into mixed vegetable pickles.

A cruciferous vegetable contains relatively highly concentrated sulphur compoundsglucosinolates. Depending on the species and cultivar, the glucosinolate content differs (Sivakumar et al., 2007), as well as the divergent edible portion of brassicaceae vegetables (Kushad et al., 1999). 77 per cent of daily vitamin C, 20 per cent of daily vitamin $\mathrm{K}$ and 10 per cent or more of daily vitamin $\mathrm{B}_{6}$ will be obtained with one cup of raw cauliflower. Cauliflower contains 80 per cent of moisture, $5.90 \mathrm{~g}$ of protein, $1.30 \mathrm{~g}$ of fat, minerals of $2.0 \mathrm{~g}, 3.20 \mathrm{~g}$ of crude fiber, 66 $\mathrm{kcal}$ of energy, $626 \mathrm{mg}$ of calcium, $107 \mathrm{mg}$ of phosphorous and $40 \mathrm{mg}$ of Iron (Gopalan et al., 2012). It acts as an immune system soldier, cancer-fighting crusader, keeps bones healthy, aids with detox, reduces blood pressure, lowers the risk of cardiovascular disease, boost brain health, skin and hair care and digestive benefits.

\section{Materials and Methods}

The experiment was conducted in medium red sandy loam soil with $\mathrm{pH} 7.00$ at Main Horticultural Research and Extension Centre (MHREC), University of Horticultural Sciences, Bagalkot, Karnataka. It is situated in Northern part of Karnataka state with $16.1635^{\circ} \mathrm{N}$ latitude and $75.6172^{\circ} \mathrm{E}$ longitude at 563 meters above sea level. The mean rainfall was about $561 \mathrm{~mm}$ with maximum temperature of $38.9^{\circ} \mathrm{C}$ and minimum temperature of $19.05^{\circ} \mathrm{C}$. The relative humidity 80.16 per cent and 40.27 per cent, respectively in the morning and evening were observed during the crop growth period. There were thirteen treatments i.e. $33 \% \mathrm{RDF}$ $+2.5 \%$ foliar spray $\left(\mathrm{T}_{1}\right), 33 \% \mathrm{RDF}+5.0 \%$ foliar spray $\left(\mathrm{T}_{2}\right), 33 \% \mathrm{RDF}+7.5 \%$ foliar spray $\left(\mathrm{T}_{3}\right), 33 \% \mathrm{RDF}$ alone $\left(\mathrm{T}_{4}\right), 50 \% \mathrm{RDF}+$ $2.5 \%$ foliar spray $\left(\mathrm{T}_{5}\right), 50 \% \mathrm{RDF}+5.0 \%$ foliar spray $\left(\mathrm{T}_{6}\right), 50 \% \mathrm{RDF}+7.5 \%$ foliar spray $\left(\mathrm{T}_{7}\right), 50 \% \mathrm{RDF}$ alone $\left(\mathrm{T}_{8}\right), 66 \% \mathrm{RDF}+$ $2.5 \%$ foliar spray $\left(\mathrm{T}_{9}\right), 66 \% \mathrm{RDF}+5.0 \%$ foliar spray $\left(\mathrm{T}_{10}\right), 66 \% \mathrm{RDF}+7.5 \%$ foliar spray $\left(\mathrm{T}_{11}\right), 66 \% \mathrm{RDF}$ alone $\left(\mathrm{T}_{12}\right)$ and $100 \%$ $\mathrm{RDF}$ alone $\left(\mathrm{T}_{13}\right)$ with three replications.Mahima-80 was used as cauliflower cultivar. Urea, SSP and MOP were used in soil application where as 19all, urea and SOP were used as water soluble fertilizers for foliar application.

Ascorbic acid content of cauliflower curd was estimated by using titration method. It was estimated titrimetrically using 2, 6dicholorophenol indophenol dye as per the modified procedure of AOAC (AOAC, 1984). For determination of total soluble solids (TSS) digital refractometer was used. Ten gram sample of fresh cauliflower from each 
replication was taken and oven dried at $65 \pm 2$ ${ }^{\circ} \mathrm{C}$ till complete moisture was lost. The percentage dry matter was then calculated by following formulae:

Fibraplus instrument was used for the analysis. The residue obtained after filtration was kept in hot air oven at $100-120{ }^{\circ} \mathrm{C}$ for 3 hours then weighed. Again, incinerated using muffle furnace at $500{ }^{\circ} \mathrm{C}$ for 1 hour, cooled and weighed again. The loss in weight gave the crude fiber content.

Cauliflower curd surface color measurements were taken at two marked points on the opposite sides at the equatorial region of the curd using Hunter colorimeter. In the color system, $+a^{*},+b^{*},-a^{*}$ and $-b^{*}$ values describe the intensity of red, yellow, green and blue color respectively. Furthermore $\mathrm{L}^{*}=$ 0 represents darkest black where as $\mathrm{L}^{*}=100$ delineates lightness.

The soil $\mathrm{pH}$ values were measured using technical model $\mathrm{pH}$ el-2 meter with combination of glass electrodes and calomel.

The electrical conductivity was measured with the aid of the electrical conductivity bridge and expressed in deciSiemens per meter $(\mathrm{dS} / \mathrm{m})$. Available nitrogen content was estimated using alkaline potassium permanganate method (Subbiah and Asija, 1956).

Available phosphorous in soil was extracted with the help of Olsen's extractant $(0.5 \mathrm{M}$ $\mathrm{NaHCO}_{3}$ ) and Darco-G-60 (activated P-free charcoal powder). Further, the filtered extract solution was determined by Stannous chloride method (Jackson, 1973). The intensity of color was read on UV spectrophotometer. The exchangeable and water soluble potassium in the soil was extracted using neutral ammonium acetate solution and was estimated by feeding it to the flame photometer.

\section{Results and Discussion}

\section{Quality parameters}

\section{Ascorbic acid (mg/100g)}

With respect to the ascorbic acid recorded for all the treatments were statistically significant. Ascorbic acid content ranged from $36.24 \mathrm{mg} / 100 \mathrm{~g}\left(\mathrm{~T}_{4}\right)$ to $45.40 \mathrm{mg} / 100 \mathrm{~g}$ $\left(\mathrm{T}_{10}\right)$ with a centered value of $41.19 \mathrm{mg} / 100 \mathrm{~g}$. The highest amount of ascorbic acid (45.40 $\mathrm{mg} / 100 \mathrm{~g})$ was recorded in the treatment $\mathrm{T}_{10}$ $(66 \% \mathrm{RDF}+5.0 \%$ foliar spray) which were on par excellence with $\mathrm{T}_{9}(44.57 \mathrm{mg} / 100 \mathrm{~g})$ followed by $\mathrm{T} 8(44.03 \mathrm{mg} / 100 \mathrm{~g})$ and $\mathrm{T} 7$ (43.37 mg/100g). Whereas, the least ascorbic acid content $(36.24 \mathrm{mg} / 100 \mathrm{~g})$ was found in the treatment $\mathrm{T}_{4}(33 \% \mathrm{RDF}$ alone).

\section{TSS ( ${ }^{\mathbf{B}}$ Brix)}

The effect of fertilizers on the results of TSS of different treatments was found to be significant. Total soluble solids in curd ranged between $3.43{ }^{\circ}$ Brix $\left(\mathrm{T}_{4}\right)$ and $4.56{ }^{\circ}$ Brix $\left(\mathrm{T}_{10}\right)$ with a average value of $4.11^{\circ}$ Brix. The highest TSS $\left(4.56{ }^{\circ}\right.$ Brix) was recorded in treatment $\mathrm{T}_{10}(66 \% \mathrm{RDF}+5.0 \%$ foliar spray $)$ followed by $\mathrm{T}_{9}\left(4.43{ }^{\circ}\right.$ Brix $), \mathrm{T}_{11}\left(4.33{ }^{\circ} \mathrm{Brix}\right)$, $\mathrm{T}_{7}\left(4.30{ }^{\circ} \mathrm{Brix}\right)$ and $\mathrm{T}_{6}\left(4.24{ }^{\circ} \mathrm{Brix}\right)$. The lowest TSS ( $3.43{ }^{\circ}$ Brix) was recorded in the treatment $\mathrm{T}_{4}$ (33\% RDF alone) followed by $\mathrm{T}_{1}$ (3.86 ${ }^{\circ}$ Brix) and these treatments were statistically on par with each other.

\section{Dry matter content of curd (\%)}

The data on dry matter content of curd showed significant differences amongst the treatments. The content varied from lowest 9.62 per cent $\left(T_{1}\right)$ to highest 11.24 per cent $\left(\mathrm{T}_{10}\right)$ with a average value of 10.45 per cent. There was an indicative difference in respect to dry matter content of curd among all the treatments. The maximum content (11.24 per 
cent) was found in $\mathrm{T}_{10}(66 \% \mathrm{RDF}+5.0 \%$ foliar spray) followed by $\mathrm{T}_{9}(66 \% \mathrm{RDF}+$ $5.0 \%$ foliar spray: $11.12 \%)$. The least content was recorded in $\mathrm{T}_{1}(9.62 \%)$ followed by $\mathrm{T}_{4}$ (9.96\%), $\mathrm{T}_{2}(10.06 \%)$ and $\mathrm{T}_{3}(10.09 \%)$. All the values were on par with each other.

\section{Crude fiber $(\mathrm{g} / \mathbf{1 0 0 g})$}

Crude fiber content was significantly different and varied from lowest $2.01 \mathrm{~g}$ per $100 \mathrm{~g}\left(\mathrm{~T}_{4}\right)$ to highest $2.47 \mathrm{~g}$ per $100 \mathrm{~g}\left(\mathrm{~T}_{10}\right)$ with a mean value of $2.25 \mathrm{~g} / 100 \mathrm{~g}$ ). The maximum content $(2.47 \mathrm{~g} / 100 \mathrm{~g})$ was found in $\mathrm{T}_{10}(66 \% \mathrm{RDF}+$ $5.0 \%$ foliar spray) followed by $\mathrm{T}_{9}(66 \% \mathrm{RDF}$ $+5.0 \%$ foliar spray: $2.38 \mathrm{~g} / 100 \mathrm{~g}$ ). The least content was recorded in $\mathrm{T}_{4}(2.01 \mathrm{~g} / 100 \mathrm{~g})$ followed by $\mathrm{T}_{1}(2.05 \mathrm{~g} / 100 \mathrm{~g}), \mathrm{T}_{3} \quad(2.07$ $\mathrm{g} / 100 \mathrm{~g})$ and $\mathrm{T}_{2}(2.11 \mathrm{~g} / 100 \mathrm{~g})$. All these treatments were on par with each other.

\section{Color values}

The data tabulated in the Table 1 depicts the intensity of color of the cauliflower. White cauliflower is specified by a high $\mathrm{L}$ value, which is a measure of lightness or darkness and $a$ low $b$ value which measures yellowness. The value of ' $L$ ', ' $a$ ' and ' $b$ ' ranged from 51.94 to $58.23,0.78$ to 3.62 and 15.39 to 18.90 respectively. The mean value of ' $\mathrm{L}$ ', ' $\mathrm{a}$ ' and 'b' was recorded 55.06, 2.52 and 16.64 respectively.

The curd with high ' $L$ ' value (58.23) was found in treatment $\mathrm{T}_{3}(33 \% \mathrm{RDF}+7.5 \%$ foliar spray) and $\mathrm{T}_{9}(58.23)$. The second best treatment was found in the treatment $\mathrm{T}_{7}$ (56.46). The lowest value was found in $\mathrm{T}_{4}$ (51.94) followed by $\mathrm{T}_{11}$ (52.83). Even though thirteen treatments were on par with each other.

In regard to low 'a' value $(0.78)$ was found in treatment $\mathrm{T}_{3}(33 \% \mathrm{RDF}+7.5 \%$ foliar spray) followed by $\mathrm{T}_{8}(0.79)$. The other best treatment was found in the treatment $T_{4}$ (1.13). The highest ' $a$ ' value was found in $T_{1}$ (3.62) followed by $\mathrm{T}_{2}$ (2.69).

Additionally, low ' $b$ ' value (15.18) was found in treatment $\mathrm{T}_{10}(66 \% \mathrm{RDF}+5.0 \%$ foliar spray) followed by $\mathrm{T}_{7}$ (15.86), $\mathrm{T}_{5}$ (15.56), $\mathrm{T}_{6}$ (15.55) and $\mathrm{T}_{2}$ (15.39. All the treatments were on par with each other.

\section{Leaf nutrient status}

\section{Nitrogen (\%)}

The mean value on nitrogen per cent of leaves was found to be 2.19 per cent and it varied from 0.94 per cent to 3.18 per cent. There was a remarkable variance obtained in nitrogen content of leaves among the treatments. The highest nitrogen content of leaves was found in the treatment $\mathrm{T}_{10}(66 \% \mathrm{RDF}+5.0 \%$ Foliar spray) with 3.18 per cent and it was significantly dissimilar from all other treatments followed by $\mathrm{T}_{9}(66 \% \mathrm{RDF}+2.5 \%$ Foliar spray: $3.05 \%$ ) and the lowest nitrogen content of leaves had been observed in treatment $\mathrm{T}_{8}(50 \% \mathrm{RDF}$ alone) with 0.94 per cent.

\section{Phosphorous (\%)}

The statistics on phosphorous per cent of leaves after harvest is given in the Table 2. The average value was found to be 0.42 per cent and it ranged from 0.22 per cent to 0.68 per cent. There was significant differentiation obtained in phosphorous content of leaves among the treatments. The highest phosphorous content of leaves was found in the treatment $\mathrm{T}_{10}(66 \% \mathrm{RDF}+5.0 \%$ Foliar spray) with 0.68 per cent and it was significantly different from all other treatments. It was succeeded by the treatment $\mathrm{T}_{9}(66 \% \mathrm{RDF}+2.5 \%$ Foliar spray: $0.62 \%)$ and $\mathrm{T}_{13}$ (100\% RDF alone: $\left.0.54 \%\right)$ the lowest phosphorous content of leaves had been 
observed in treatment $\mathrm{T}_{7}(50 \% \mathrm{RDF}+7.5 \%$ foliar spray) with 0.22 per cent.

\section{Potassium (\%)}

The mean value was found to be 1.10 per cent and it varied from 0.88 per cent to 1.34 per cent. There was significant differentiation obtained in potassium content of leaves among the treatments. The highest potassium content of leaves was found in the treatment $\mathrm{T}_{10}(66 \% \mathrm{RDF}+5.0 \%$ Foliar spray) with 1.34 per cent which was notably peak among the treatments. This treatment was followed by $\mathrm{T}_{9}$ $(66 \% \mathrm{RDF}+2.5 \%$ Foliar spray: $1.27 \%)$ and $\mathrm{T}_{11}(66 \% \mathrm{RDF}+7.5 \%$ Foliar spray: $1.18 \%)$. The lowest potassium content of leaves had been observed in treatment $\mathrm{T}_{6}(50 \% \mathrm{RDF}+$ $5.0 \%$ foliar spray) with 0.88 per cent.

\section{Sulphur (\%)}

It was ranged between 2.53 per cent and 3.75 per cent with a mean value of 3.28 per cent. There was remarkable difference found in sulphur content of leaves among the treatments. The highest sulphur content of leaves was found in the treatment $\mathrm{T}_{10}(66 \%$ $\mathrm{RDF}+5.0 \%$ Foliar spray) with 3.75 per cent and found notably highest when compared with the other treatments. The other subsequent highest was observed by the treatment $\mathrm{T}_{9}(66 \% \mathrm{RDF}+2.5 \%$ Foliar spray: $3.59 \%)$ followed by $\mathrm{T}_{7}(50 \% \mathrm{RDF}+7.5 \%$ Foliar spray: $3.51 \%$ ). The lowest sulphur content of leaves was inscribed in the treatment $\mathrm{T}_{8}$ (33\% RDF alone) with 2.53 per cent.

\section{Soil nutrient status}

\section{Soil pH}

The soil $\mathrm{pH}$ results were accounted significantly contrasting from each other in the treatments. The highest $\mathrm{pH}$ value (8.44) was found in $\mathrm{T}_{9}(66 \% \mathrm{RDF}+2.5 \%$ foliar spray) which were statistically at par with $\mathrm{T}_{7}$ (50\% RDF $+7.5 \%$ foliar spray: 8.41$)$. The average soil $\mathrm{pH}$ was found to be 7.86 . However, the least value (6.14) of soil $\mathrm{pH}$ was found in the $\mathrm{T}_{13}(100 \% \mathrm{RDF}$ alone).

\section{Soil electrical conductivity}

The data on soil electrical conductivity varied between $0.11 \mathrm{dS} / \mathrm{m}$ to $0.24 \mathrm{dS} / \mathrm{m}$ with average value of $0.15 \mathrm{dS} / \mathrm{m}$. The maximum soil EC $(0.24 \mathrm{dS} / \mathrm{m})$ was found in $\mathrm{T}_{5}(50 \% \mathrm{RDF}+$ $2.5 \%$ foliar spray) and it was significantly contrasting with all other treatments. It was followed by $\mathrm{T}_{8}(50 \% \mathrm{RDF}$ alone: $0.19 \mathrm{dS} / \mathrm{m})$ and $\mathrm{T}_{10}(66 \% \mathrm{RDF}+5.0 \%$ foliar spray 0.18 $\mathrm{dS} / \mathrm{m})$. The least EC was recorded in $\mathrm{T}_{1}(0.11$ $\mathrm{dS} / \mathrm{m})$.

\section{Available nitrogen, phosphorous and potassium (kg/ha)}

The available nitrogen content was maximum $(188.67 \mathrm{~kg} / \mathrm{ha})$ in $\mathrm{T}_{11}(66 \% \mathrm{RDF}+7.5 \%$ foliar spray) which was significantly exorbitant than the average value of $117.43 \mathrm{~kg} / \mathrm{ha}$. Next best treatment was $\mathrm{T}_{13}(50 \% \mathrm{RDF}+2.5 \%$ foliar spray) with $155.33 \mathrm{~kg} / \mathrm{ha}$ which was at par with the application of $\mathrm{T}_{3}(33 \% \mathrm{RDF}+7.5 \%$ foliar spray: $155.00 \mathrm{~kg} / \mathrm{ha}$ ). However, the minimum $(56.33 \mathrm{~kg} / \mathrm{ha})$ available nitrogen was recorded in $\mathrm{T}_{7}(50 \% \mathrm{RDF}+7.5 \%$ foliar spray).

The available phosphorous content was maximum $(29.69 \mathrm{~kg} / \mathrm{ha})$ in $\mathrm{T}_{11}(66 \% \mathrm{RDF}+$ $7.5 \%$ foliar spray) which was significantly more than the average value of $22.31 \mathrm{~kg} / \mathrm{ha}$. Next best treatment was $\mathrm{T}_{12}$ (66\% RDF alone) with $27.89 \mathrm{~kg} / \mathrm{ha}$ which was at par with the treatment of $\mathrm{T}_{8}$ (33\% RDF alone: 27.82 $\mathrm{kg} / \mathrm{ha})$. However, the minimum $(16.04 \mathrm{~kg} / \mathrm{ha})$ available phosphorous was recorded in $\mathrm{T}_{6}$ (50\% RDF + $5.0 \%$ foliar spray). 
Table.1 Effect of different concentration of RDF and WSF on quality parameters of cauliflower

\begin{tabular}{|c|c|c|c|c|c|c|c|}
\hline \multirow[t]{2}{*}{ Treatments } & \multirow{2}{*}{$\begin{array}{l}\text { Ascorbic acid } \\
\text { (mg/100g) }\end{array}$} & \multirow{2}{*}{$\begin{array}{c}\text { TSS } \\
\left({ }^{0} \text { Brix }\right)\end{array}$} & \multirow{2}{*}{$\begin{array}{c}\text { Dry matter } \\
\text { content of curd } \\
(\%)\end{array}$} & \multirow{2}{*}{$\begin{array}{l}\text { Crude fiber } \\
\quad(\mathrm{g} / \mathbf{1 0 0 g})\end{array}$} & \multicolumn{3}{|c|}{ Color values } \\
\hline & & & & & $\mathbf{L}$ & $\mathbf{a}$ & b \\
\hline $\mathrm{T}_{1}: 33 \%$ RDF + $2.5 \%$ Foliar spray & 37.85 & 3.86 & 9.62 & 2.05 & 55.51 & 3.62 & 17.20 \\
\hline $\mathrm{T}_{2}: \mathbf{3 3 \%} \mathrm{RDF}+\mathbf{5 . 0 \%}$ Foliar spray & 37.03 & 4.03 & 10.06 & 2.11 & 56.39 & 2.69 & 15.39 \\
\hline$T_{3}: 33 \%$ RDF $+7.5 \%$ Foliar spray & 39.22 & 4.10 & 10.09 & 2.07 & 58.23 & 0.78 & 17.69 \\
\hline $\mathrm{T}_{4}: 33 \%$ RDF alone & 36.24 & 3.43 & 10.34 & 2.01 & 51.94 & 1.13 & 16.21 \\
\hline $\mathrm{T}_{5}: \mathbf{5 0 \%} \mathrm{RDF}+\mathbf{2 . 5 \%}$ Foliar spray & 39.30 & 4.16 & 9.96 & 2.36 & 53.86 & 2.63 & 15.56 \\
\hline $\mathrm{T}_{6}: \mathbf{5 0 \%} \mathrm{RDF}+\mathbf{5 . 0 \%}$ Foliar spray & 41.50 & 4.24 & 10.88 & 2.32 & 53.16 & 2.15 & 15.55 \\
\hline $\mathrm{T}_{7}: 50 \%$ RDF $+7.5 \%$ Foliar spray & 43.37 & 4.30 & 10.76 & 2.26 & 56.46 & 2.01 & 15.86 \\
\hline $\mathrm{T}_{8}: \mathbf{5 0 \%} \mathrm{RDF}$ alone & 44.03 & 3.90 & 10.18 & 2.15 & 54.06 & 0.78 & 16.92 \\
\hline $\mathrm{T}_{9}: 66 \%$ RDF + $2.5 \%$ Foliar spray & 44.57 & 4.43 & 11.07 & 2.38 & 58.23 & 2.06 & 17.98 \\
\hline$T_{10}: 66 \%$ RDF + 5.0\% Foliar spray & 45.40 & 4.56 & 11.24 & 2.47 & 55.58 & 2.48 & 17.02 \\
\hline$T_{11}: 66 \%$ RDF + 7.5\% Foliar spray & 42.31 & 4.33 & 10.25 & 2.37 & 52.83 & 2.64 & 18.90 \\
\hline $\mathrm{T}_{12}: 66 \%$ RDF alone & 41.21 & 3.93 & 10.27 & 2.23 & 54.19 & 2.30 & 16.97 \\
\hline$T_{13}: 100 \%$ RDF alone & 43.39 & 4.06 & 11.12 & 2.39 & 55.28 & 1.98 & 15.18 \\
\hline Mean & 41.19 & 4.11 & 10.45 & 2.25 & 55.06 & 2.52 & 16.64 \\
\hline SE $\mathbf{m} \pm$ & 1.49 & 0.29 & 1.06 & 0.05 & 2.46 & 0.58 & 1.02 \\
\hline $\mathrm{CD}(5 \%)$ & 4.34 & 0.84 & NS & 0.15 & NS & 1.68 & 2.97 \\
\hline $\mathrm{CV} \%$ & 6.30 & 12.20 & 17.50 & 3.90 & 7.70 & 39.60 & 10.60 \\
\hline
\end{tabular}


Table.2 Effect of different concentration of RDF and WSF on leaf nutrient

\begin{tabular}{|c|c|c|c|c|}
\hline Treatments & Nitrogen $(\%)$ & Phosphorous (\%) & Potassium (\%) & Sulphur (\%) \\
\hline $\mathrm{T}_{1}: 33 \%$ RDF + $2.5 \%$ Foliar spray & 2.30 & 0.30 & 1.04 & 3.13 \\
\hline $\mathrm{T}_{2}: 33 \%$ RDF $+5.0 \%$ Foliar spray & 2.83 & 0.53 & 1.06 & 3.22 \\
\hline $\mathrm{T}_{3}: 33 \%$ RDF $+7.5 \%$ Foliar spray & 2.45 & 0.39 & 1.30 & 3.30 \\
\hline $\mathrm{T}_{4}: 33 \% \mathrm{RDF}$ alone & 1.04 & 0.43 & 1.07 & 2.53 \\
\hline $\mathrm{T}_{5}: 50 \%$ RDF + $2.5 \%$ Foliar spray & 1.96 & 0.32 & 0.96 & 3.27 \\
\hline $\mathrm{T}_{6}: 50 \%$ RDF + 5.0\% Foliar spray & 1.54 & 0.35 & 0.88 & 3.43 \\
\hline $\mathrm{T}_{7}: 50 \%$ RDF $+7.5 \%$ Foliar spray & 1.70 & 0.22 & 0.90 & 3.51 \\
\hline $\mathrm{T}_{8}: 50 \%$ RDF alone & 0.94 & 0.33 & 1.12 & 3.43 \\
\hline$T_{9}: 66 \%$ RDF + $2.5 \%$ Foliar spray & 3.05 & 0.62 & 1.27 & 3.59 \\
\hline$T_{10}: 66 \%$ RDF + 5.0\% Foliar spray & 3.18 & 0.68 & 1.34 & 3.75 \\
\hline $\mathrm{T}_{11}: 66 \%$ RDF $+7.5 \%$ Foliar spray & 2.27 & 0.43 & 1.18 & 3.24 \\
\hline$T_{12}: 66 \%$ RDF alone & 2.56 & 0.38 & 1.11 & 3.16 \\
\hline$T_{13}: 100 \%$ RDF alone & 2.75 & 0.54 & 1.17 & 3.15 \\
\hline Mean & 2.19 & 0.42 & 1.10 & 3.28 \\
\hline SE $\mathbf{m} \pm$ & 0.03 & 0.01 & 0.01 & 0.01 \\
\hline CD (5\%) & 0.06 & 0.02 & 0.02 & 0.04 \\
\hline CV \% & 1.80 & 3.30 & 1.10 & 0.70 \\
\hline
\end{tabular}

RDF: Recommended dose of fertilizers

WSF: Water soluble fertilizers

DAT= Days after transplanting

Table.3 Effect of different concentration of RDF and WSF on soil nutrient

\begin{tabular}{|c|c|c|c|c|c|}
\hline Treatments & Soil pH & $\mathrm{EC}(\mathrm{dS} / \mathrm{m})$ & $\begin{array}{c}\text { Available } \\
\text { Nitrogen } \\
\text { (kg/ha) }\end{array}$ & $\begin{array}{c}\text { Available } \\
\text { phosphorous } \\
\text { (kg/ha) }\end{array}$ & $\begin{array}{c}\text { Available } \\
\text { potassium } \\
\text { (kg/ha) }\end{array}$ \\
\hline $\mathrm{T}_{1}: 33 \%$ RDF + 2.5\% Foliar spray & 7.82 & 0.11 & 127.33 & 25.17 & 68.33 \\
\hline $\mathrm{T}_{2}: 33 \%$ RDF + 5.0\% Foliar spray & 7.23 & 0.16 & 95.33 & 22.90 & 71.33 \\
\hline $\mathrm{T}_{3}: 33 \%$ RDF + 7.5\% Foliar spray & 8.30 & 0.12 & 155.00 & 21.18 & 73.67 \\
\hline$T_{4}: 33 \%$ RDF alone & 8.35 & 0.13 & 126.67 & 18.54 & 76.00 \\
\hline $\mathrm{T}_{5}: 50 \%$ RDF + $2.5 \%$ Foliar spray & 7.87 & 0.24 & 84.67 & 17.03 & 68.00 \\
\hline $\mathrm{T}_{6}: \mathbf{5 0 \%}$ RDF + 5.0\% Foliar spray & 8.05 & 0.13 & 94.67 & 16.04 & 75.67 \\
\hline $\mathrm{T}_{7}: \mathbf{5 0 \%} \mathrm{RDF}+\mathbf{7 . 5 \%}$ Foliar spray & 8.41 & 0.15 & 56.33 & 19.36 & 60.00 \\
\hline$T_{8}: 50 \%$ RDF alone & 8.32 & 0.19 & 125.67 & 27.82 & 72.33 \\
\hline$T_{9}: 66 \%$ RDF + $2.5 \%$ Foliar spray & 8.44 & 0.15 & 93.67 & 22.72 & 74.00 \\
\hline$T_{10}: 66 \%$ RDF + 5.0\% Foliar spray & 7.44 & 0.18 & 95.67 & 18.84 & 56.67 \\
\hline$T_{11}: 66 \%$ RDF $+7.5 \%$ Foliar spray & 8.35 & 0.14 & 188.67 & 29.69 & 87.33 \\
\hline$T_{12}: 66 \%$ RDF alone & 7.56 & 0.15 & 125.67 & 27.89 & 84.00 \\
\hline$T_{13}: 100 \%$ RDF alone & 6.14 & 0.13 & 155.33 & 22.89 & 62.67 \\
\hline Mean & 7.86 & 0.15 & 117.43 & 22.31 & 71.54 \\
\hline SE $\mathbf{m} \pm$ & 0.03 & 0.01 & 1.02 & 0.45 & 0.82 \\
\hline CD $(5 \%)$ & 0.07 & $\mathbf{0 . 0 2}$ & 2.98 & 1.30 & 2.38 \\
\hline CV \% & 0.60 & 9.20 & 1.50 & 3.50 & 2.00 \\
\hline
\end{tabular}

RDF: Recommended dose of fertilizers

EC: Electrical Conductivity

WSF: Water soluble fertilizers

DAT: Days after transplanting 
The available potassium content was maximum $(87.33 \mathrm{~kg} / \mathrm{ha})$ in $\mathrm{T}_{11}(66 \% \mathrm{RDF}+$ $7.5 \%$ foliar spray) which was substantially higher than the average value of $71.54 \mathrm{~kg} / \mathrm{ha}$. Next best treatment was $\mathrm{T}_{10}(66 \% \mathrm{RDF}+$ $5.0 \%$ foliar spray) with $84 \mathrm{~kg} / \mathrm{ha}$ followed by $76 \mathrm{~kg} / \mathrm{ha}$ in $\mathrm{T}_{4}(33 \% \mathrm{RDF}$ alone) which was at par with the treatment $\mathrm{T}_{6}(50 \% \mathrm{RDF}+5.0 \%$ foliar spray: $75.67 \mathrm{~kg} / \mathrm{ha})$. However, the minimum (56.67 $\mathrm{kg} / \mathrm{ha}) \quad$ available phosphorous was recorded in $\mathrm{T}_{10}(66 \% \mathrm{RDF}+$ $5.0 \%$ foliar spray).

The treatment $\mathrm{T}_{10}(66 \% \mathrm{RDF}+5.0 \%$ foliar application) was found superior with highest ascorbic acid content $(45.40 \mathrm{mg} / 100 \mathrm{~g})$, TSS content (4.56 ${ }^{\circ}$ Brix), dry matter content of curd $(11.24 \%)$ and crude fiber content $(2.47 \mathrm{~g}$ $/ 100 \mathrm{~g}$ ) compared to other treatments. The rise in TSS may be accredited to the production of substances that could have accelerated the synthesis of carbohydrates, vitamins and other qualitative characteristics. Surplus availability of nutrients results in greater uptake of nutrient and more increase photosynthesis which enhances translocation of photosynthates and food accumulation in edible part resulting in increase in dry matter content, on the other hand decreases per cent of moisture content.

These findings are in close agreement with Kumar et al., (2017), lower dose of nitrogen and split application gave higher dry matter content of tuber of potato and it was falling off with the increase in nitrogen dose. The color values showed a typical whitish creamy color of the cultivar, and were affected by treatments or storage times. Lightness $\left(\mathrm{L}^{*}\right)$, $\left(a^{*}\right.$ and $\left.b^{*}\right)$ were not affected by treatments at first two to three days of storage. There was an inclination for increased $\mathrm{L}^{*}, \mathrm{a}^{*}$ and $\mathrm{b}^{*}$ values with greater storage time within each treatment (Table 1).

The data tabulated in the table 2 illustrates significant contrast amidst the treatments with reference to nutrient status in foliage. Maximum per cent of $\mathrm{N}, \mathrm{P}, \mathrm{K}$ and $\mathrm{S}$ in leaves were recorded in treatment $\mathrm{T}_{10}(3.18 \%, 0.68$ $\%, 1.34 \%$ and $3.75 \%$ respectively). This might be due to increasing the fertilizer application rate which also increases the uptake of nutrients in plants. Furthermore, it has been determined that foliar fertilization does not fully replace soil-added fertilizer, but it increases the absorption and thus the nutrient output added to the soil (Tejada and Gonzalez, 2004). One of the advantages of foliar fertilization is greater soil nutrient absorption. This theory is based on the assumption that the foliar fertilization allows the plant to release more sugars and other exudates into the rhizosphere from its roots. The increased availability of these exudates is stimulating beneficial microbial communities in the root zone. Such enhanced biological activity in turn enhances the plant's supply of beneficial nutrients, disease-suppressive biochemicals, vitamins and other important factors.

The analysis of variance disclosed that there was considerably contrast between the different concentrations of fertilizer treatments as presented table 3. The treatment $\mathrm{T}_{10}$ which was superior in all with respect to the growth, yield, quality parameters had soil $\mathrm{pH}$ of 7.44, EC of $0.18 \mathrm{dS} / \mathrm{m}, \mathrm{N} 95.67 \mathrm{~kg} / \mathrm{ha}$, $\mathrm{P} 18.84 \mathrm{~kg} / \mathrm{ha}$ and $\mathrm{K} 56.67 \mathrm{~kg} / \mathrm{ha}$. From this it can be concluded that plant took abundance of nutrients- when supplied in three split dose, from soil as well as foliage resulting in best quality curd. Although, soil productivity sustainability depends on intrinsic soil properties or soil quality and extrinsic factors including landscape quality factors such as precipitation, temperature, topography and hydrology. Soil type, species and functions, carbon and energy, and nutrients are factors influencing the soil quality (El-Ramady, 2014). 
In conclusion the foliar feeding is a simple nutrient corrective technique used in vegetable crops during the growth cycle when soil application is ineffective and lets to hazards as expensive. From the above findings it was concluded that the application of inorganic fertilizers at 66 per cent recommended dose of fertilizers with $5.0 \%$ foliar application $\left(T_{10}\right)$ is best for quality of curd, nutrient content and post harvest status of soil. It increases the efficacy of cauliflower plant nutrient uptake and reduces the soil pollution. This recommendation could help to upsurge cauliflower yield by implementing in large scale farming to extract good quality of cauliflower and a fruitful return.

\section{References}

Chatterjee, S. S. and Swarup, V., 1972, Indian cauliflower has as till greater future. Indian Hort., 10: 18-20.

El-Ramady, H., R., Alshaal, T., A., Amer, M., Domokos-Szabolcsy, E., Elhawat, N., Prokisch, J. and Fari, M., 2014, Soil quality and plant nutrition, Sustainable Agriculture Reviews, 14: 345-447.

Gopalan, C., Rama Sastri, B. V. and Balasubramanian, S. C., 2012, Nutritive value of foods. National Institute of Nutrition, Indian Council of Medical Research (ICMR): 47-58.

Jackson, M. L., 1973, Soil chemical analysis. Prentice Hall of India Pvt. Ltd., New Delhi, 498.
Kowsalya, S., and Sangeetha, M., 1999, Acceptability and nutrient profile of cauliflower leaves (Brassica oleraceae var botrytis), Indian J. Nutr. Diet., 36. 332-338.

Kumar, U., Chandra, G. and Raghav, M., 2017, Split application of nitrogen in potato for maximum tuber yield and quality. Bull. Env. Pharmacol. Life Sci., 6(1): 296-301.

Kushad, M. M., Brown, A. F., Kurilich, A. C., Juvik, J. A., Klein, B. P., Wallig, M. A. and Jeffery, E. H., 1999, Variation of glucosinolates in vegetable crops of Brassica oleracea. J. Agri. Food Chem., 47(4): 1541-1548.

Pavan Kumar, P., Vijay Rakesh Reddy, S., Gajanan, G. and Varun, M.H., 2018, Recent update of Horticultural Statistics: Indian Horticos.

Sivakumar, G., Aliboni, A. and Bacchetta, L., 2007, HPLC screening of anti-cancer sulforaphane from important European Brassica species. Food Chem., 104(4): 1761-1764.

Subbiah, B. and Asija, G., 1956, A rapid procedure for the estimation of available nitrogen in soils. Curr. Sci., 25: $259-260$.

Tejada, M. and Gonzalez, J. L., 2004. Effects off foliar application of a byproduct of the two-step olive oil mill process on rice yield. Eur. J. Agron., 21: 31-40

\section{How to cite this article:}

Krish Rauniyar, Vasant M. Ganiger, T. B. Alloli, G. Bhuvaneswari, J. B. Gopali, S. M. Prasanna and Anand G. Patil. 2021. Cumulative Effect of Soil and Water Soluble Fertilizer on Physio-biochemical, Nutrient Status of Leaf and its Effect on Postharvest Soil in Cauliflower Production. Int.J.Curr.Microbiol.App.Sci. 10(01): 2836-2844. doi: https://doi.org/10.20546/ijcmas.2021.1001.329 